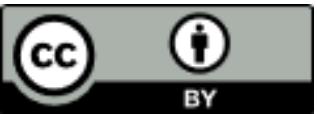

UDC 81'342.111=111

Original scientific article

Accepted for publication on 03.01. 2019 https://doi.org/10.29162/jez.2019.17

\title{
Andrej Stopar
}

University of Ljubljana

\section{Perception of General British monophthongs: The case of Slovene students of English as a foreign language}

\begin{abstract}
The paper presents an experimental study on the perception of the General British monophthongs that was conducted in three stages in 2014-2018. The vowels observed are studied by (i) comparing the vowel systems of General British and Slovene, and (ii) by conducting an experiment on their perception. The analysis focuses on the participants' overall performance, their most frequent misperceptions, and their progress over the course of one semester. The results indicate: that the previously observed production difficulties mirror perception difficulties; that the discriminative failures of FL vowels are not entirely predictable by comparing vowel systems; that new sound contrasts are assimilated in different ways; and that the participants' perception of foreign language phonemes can benefit from explicit instruction.
\end{abstract}

Key words: perception of vowels; General British vowels; Slovene vowels; foreign language phonetics; Slovene learners of EFL.

\section{Introduction and literature review}

\subsection{Perception of sounds}

Speech perception has been described as "the cognitive process of assigning labels to the incoming signal" (Tatham \& Morton 2011: 126). In decoding a sound wave, the hearer/listener analyses the signal physically before assigning it a symbolic representation suitable for further syntactic and semantic processing. According to Tatham and Morton (2011: 152-168), some theories of speech perception (for example, that of Liberman et al. 1967) posit that the interpretation of the sound wave occurs on the level of sound segments. The listener thus interprets the acoustic information in terms of the type of articulation required to produce the perceived sig- 


\section{Andrej Stopar: \\ Perception of General British monophthongs: The case of Slovene students of English as a foreign language}

nal, or in terms of various acoustic parameters that define a certain segment (for example, voicing).

The process described above is complex, especially since the sounds that are often perceived as identical are, in reality, often different and merely occurring "on the same production cline" (Tatham \& Morton 2011: 159). Hence, phonologically different segments can be assigned the same labels. The frequencies associated with a vowel may change depending, for example, on the surrounding sounds, but the vowel will still be successfully perceived. The categorisation of speech sounds on this cline is language-dependent. The various positions of the speech organs in different languages may result either in a helpful overlap or, in some cases, in an undesired "perceptual confusion" (Tatham \& Morton 2011: 160).

For a foreign language (FL) learner, a reliable and consistent perception (and production) of the target language sounds is vital. Learners are often required to master the ability to discriminate between sound contrasts that are non-existent in their mother tongue (L1). To develop this ability, they rely heavily on their linguistic background, i.e., on the categories associated with the phonetic system of their L1.

According to Flege (1995), in the process of L2 acquisition new categories are more likely to be established when the perceived distance between the L1 vowel and L2 vowel is greater. In the case of less distant pairs of vowels, new categories are less likely to be created. Hence, when a pair of L2 vowels is identified as a single L1 category, discriminative failures can be expected.

A similar relationship between L1 and L2/FL is described by Best (1995: 185), who claims that the "perceivers become [...] increasingly adept and efficient at detecting the critically distinguishing properties" of their L1 phonological inventory. In time, the amount of information needed to perceive the various L1 sounds is so compacted and reduced that only the relevant features are relied upon to discriminate between different sounds. Naturally, this compacting in native speech affects the perception of non-native speech. Best suggests that the assimilation of new phonemes occurs in various ways: for example, a pair of non-native segments can be assimilated to different native categories, to the same native category, outside any particular native category, and the like. The type of assimilation affects the success of discrimination.

Regardless of the various approaches to explaining speech perception, it has been well-attested in the literature that FL learners can learn to discriminate between new sounds. Escudero (2000), for example, illustrates this with the Scottish 


\section{EZIKOSLOVLJE \\ 20.3 (2019): 475-496}

vowel pair of /I/ and /i:/. The Spanish speakers included in the study progressed from their initial inability to discriminate between the two sounds, to perceiving the difference based on duration, and finally to perceiving the difference in both duration and spectral properties of the sounds.

Also relevant are those studies that explore the correlations between perception and production. For example, in their study of Brazilian speakers of L2 English, Bion et al. (2006) stress the strong relationship between L2 vowel perception and production, with successful perception being identified as a prerequisite for production. Baker and Trofimovich (2006) reach a similar conclusion after studying the relationship in a group of Korean learners of English. In the case of Slovene learners of English as a foreign language (EFL), some issues related to the vowel space have been empirically and experimentally attested by Šuštaršič (2005), Stopar $(2015$; 2017) and Komar (2017). Focusing on the typical production and/or perception difficulties of Slovene EFL learners, these studies compare the General British (GB) and Slovene (StS) vowel systems.

Considering the relative complexity of the GB vowel system, it is hardly a surprise that EFL learners encounter difficulties in both production and perception of vowel contrasts. Cruttenden (2014: 109) states that some of the most challenging issues in the GB vowel space are represented by vowel groups that are "closest within the vowel space", which is in line with the categorical perception theories presented above. As claimed by Saito (2012), teachers can work on such challenges by relying on explicit instruction of pronunciation based on a variety of factors that also include the L1 background of their students.

\subsection{Comparing the vowel systems: General British and Slovene}

As illustrated by Petek et al. (1996), Šuštaršič et al. (1995), Srebot-Rejec (1988a; 1988 b), and Šuštaršič $(2004 ; 2005)$, one of the immediately detectable differences between the GB and Slovene vowel systems is in the number of vowel phonemes. The two systems of monophthongs are presented in Figure 1 (cf. Šuštaršič \& Komar 1999: 137; Wells 2008: xxiii-xxv). ${ }^{1}$

\footnotetext{
${ }^{1}$ The vowel systems presented here are limited to the 'standard' varieties of the investigated languages. It should be noted, however, that L1 dialect interference has also been shown to play a role in EFL phonetics - for a relevant analysis of the Slovene context, see Jurančič Petek (2014).
} 


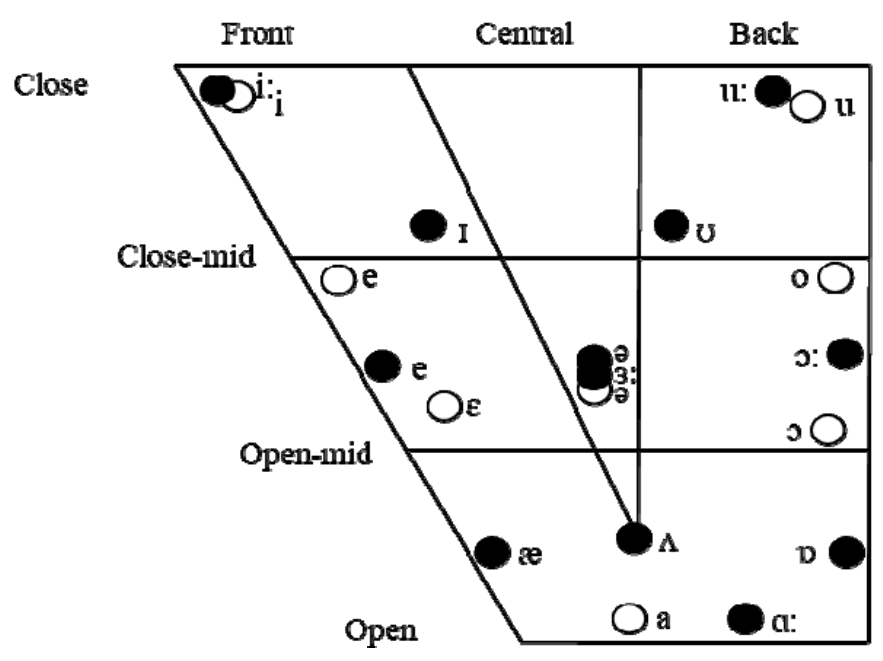

Figure 1. The vowel quadrilateral comparing GB (black circles) and StS (white circles) monophthongs

As established by Šuštaršič (2005: 9), for each of the GB long and short vowel pairs /i: - I, u: - $\mho$, a: - $\Lambda$ / Slovene "only has a (relatively) close front and a (relatively) close back vowel /i, u/ and an open central vowel /a/, which are all relatively long in accented and relatively short in unaccented position[s]."

The absence of a number of contrasts in the vowel system of StS poses a challenge for Slovene EFL learners. The set of eight Slovene monophthongs has to be relied upon to assimilate thirteen GB sounds. The question arises, of course, how the closest phonemes in the vowel space interact. Some specific issues which have been discussed in the literature are presented below.

\subsubsection{StS /i/ and GB /i:/, /I/}

Slovene speakers are likely to neutralise the difference between the GB vowels FLEECE $^{2}$ /i:/ and KIT /I/ (Šuštaršič 2005: 12). Nevertheless, the GB FLEECE-vowel /i:/ is closer to the StS / $\mathrm{i}$ ( as in <tri> 'three'), while the GB KIT / $/$ / is moving in the direction of $\mathrm{StS} / \mathrm{e} /$ (as in $<\mathrm{dve}>$ 'two').

\subsubsection{StS/e/, /E/ and $G B / e /$, /æ/}

An example of a potential difficulty for Slovene EFL learners is the opposition of Slovene vowel phonemes /e/ and $/ \varepsilon /$ (as in <pet> 'five' and <peta> 'heel'), on the

\footnotetext{
${ }^{2}$ Wells' (1982) standard lexical sets for English are used to refer to the relevant English vowels.
} 


\section{EZIKOSLOVLJE \\ 20.3 (2019): 475-496}

one hand, and the GB phonemes DRESS /e/ and TRAP /æ/ on the other. ${ }^{3}$ In spite of their proximity to the GB open-mid to close-mid DRESS /e/ and the open to openmid TRAP /æ/, the Slovene close-mid and open-mid front vowels /e/ and $/ \varepsilon /$ are almost never perceived as interchangeable. Šuštaršič (2005: 10) suggests that this is due to Slovene /e/ being "perceived by Slovene speakers as too close to be applied for the English /e/."

The proximity of StS /E/, GB DRESS /e/ and GB TRAP/æ/ sometimes results in discriminative failures that have been identified in student transcriptions (Šuštaršič 2005: 83) and their oral production performance (Komar 2017: 165-166). Often the two GB vowels converge and are pronounced as the Slovene $/ \varepsilon /$, which is an unwanted intrusion of L1 into L2 since "it interferes with the maintenance of contrasts carrying a high functional load" (Cruttenden 2014: 335-336). Both perceptive and productive problems with the GB DRESS /e/ and TRAP/æ/ have been observed in other Slavic languages as well: see Marković (2009) and Čubrović (2017; 2019) for Serbian, for example.

\subsubsection{StS /a/ and GB /N/, /a:/}

A further examination of the quadrilateral reveals some other potential challenges for Slovene EFL speakers/listeners. Firstly, two different GB monophthongs - the STRUT-vowel $/ \mathrm{N} /$ and the PALM-vowel /a:/ - are likely to correspond to the StS phoneme /a/. If the present discussion were limited solely to the comparison of the GB and $\mathrm{StS}$ vowel systems, the expected perception and production issues for Slovene speakers of English would almost certainly pertain to the maintenance of the contrast between GB STRUT / $/$ / and PALM /a:/. Even the difference in length of the two GB phonemes may not be helpful, as the length of StS /a/ varies - it is long in stressed syllables and short in unstressed ones, which can be illustrated in the transcription of the Slovene word <mama> ('mother'): /'ma:ma/. Moreover, according to Šuštaršič (2005: 12), the quality of the $\mathrm{StS} / \mathrm{a} /$ is closer to GB $/ \Lambda /$.

A factor that might further complicate matters is the ubiquitous presence of American pronunciation in the media, which might affect, for example, the perception of GB STRUT $/ \Lambda /$ and PALM /a:/ vowels, with the possible complication of GB

\footnotetext{
3 The vowel /æ/ is transcribed as /a/ in the latest edition of Gimson's Pronunciation of English (Cruttenden 2014).
} 


\section{Andrej Stopar: \\ Perception of General British monophthongs: The case of Slovene students of English as a foreign language}

/a:/ corresponding to General American (GA) /æ/ in words belonging to the BATH lexical set (cf. Ladefoged 1999 for more). ${ }^{4}$

\subsubsection{St $S / \mathrm{o} / \mathrm{l} / \mathrm{o} /$ and $G B / \mathrm{p} / \mathrm{s} / \mathrm{s}: /$}

With regard to the GB LOT- /p/ and THOUGHT-vowels / $/ \mathrm{s} /$, it can be assumed that the former could correspond to the StS vowel /o/ (in, for example, ona 'her'), while the latter seems closer to $\mathrm{StS} / \mathrm{o} /$ (in, for example, olje 'oil'), which, according to Šuštaršič (2005: 12), makes the GB vowel pair " "unproblematic' [...] from the viewpoint of Slovene usage."

In relation to the American pronunciation, some potential pitfalls in the back vowel region can be foreseen since GB LOT /p/ usually corresponds to /a/ in GA but can also correspond to $/ \mathrm{s} /$ before certain fricatives and velars. Also, as some GA speakers lack the /o/ vowel and merge it with /a/, GB /o:/ can correspond to both GA /a/ and /o/ (cf. Cruttenden 2014: 129; Ladefoged 1999).

\subsubsection{StS $/ u /$ and $G B / \mho /, / u: /$}

The StS vowel /u/ is similar in the degree of opening to the GB GOOSE-vowel /u:/. The production study by Šuštaršič (2005), however, also showed that the $\mathrm{StS} / \mathrm{u}$ / "is somehow 'between' the two nearest E[nglish] equivalents in a similar way as the $\mathrm{S}[\mathrm{tS}] / \mathrm{i} /$ " (2005: 12).

\subsubsection{St $S / 2 /$ and $G B / 3: /$}

The two StS and GB vowels occupy the central space of the vowel quadrilateral. Šuštaršič's (2005) production study finds the English one to be more open than the Slovene one.

\section{The study}

As the characteristics of the vowel systems described in the sections above are likely to affect the perception of vowel contrasts by Slovene EFL learners, this paper explores to what extent the difficulties in the perception of vowel contrasts by Slovene EFL learners are present across the vowel space inhabited by GB monoph-

\footnotetext{
${ }^{4}$ Some interesting data on the self-reported exposure of Slovene students to the different varieties of English is available in Hirci (2017: 99).
} 


\section{EZIKOSLOVLJE \\ 20.3 (2019): 475-496}

thongs. The experimental data on perception performance is collected and examined in terms of categorial distance, influencing factors, and potential headway in the EFL context.

\subsection{Participants and background}

The study was conducted in three parts in the years 2014-18 and it included a total of 208 participants: 54 in the academic year 2014-15, 82 in 2016-17, and 72 in 2017-18. The 208 respondents were first-year BA students of English at the University of Ljubljana, with a comparable linguistic background: their L1 is Slovene, and to begin their studies in the English Department they had to sit the Matura, the national secondary school-leaving examination in English. ${ }^{5}$ The participants' ages ranged from 17 to 25 , the average being $19.2(\sigma=1.0, \mu 1 / 2=19)$. With regard to their gender, $76 \%$ of the participants were female, which reflects the usual gender structure at the English Department in the University of Ljubljana.

In their first semester at the Department, the students are required to take the course English Phonetics and Phonology, which consists of fifteen 90-minute lectures and fifteen 90-minute practice classes. The course covers general phonetics while focusing on the main features of the English sound system in terms of articulatory features and auditory perception. Students are also taught phonemic and some aspects of phonetic transcription. The experimental part of the study was conducted in the first semester of the participants' studies, after the participants had been familiarised with the IPA symbols for GB phonemes. The practical exercises aimed at vowel perception encompassed IPA transcription practice in the form of dictation; listen-and-repeat exercises on vowel contrasts (from Collins et al. 2006; Collins et al. 2014); transcription and discussion of minimal pairs (dictated or textbased); and allophonic transcription of vowel length pertaining to pre-fortis clipping (Wells 2008: 155).

\subsection{Instruments and procedure}

The participants were invited to fill in a two-part questionnaire. In the first section they were asked to indicate their age, gender, and mother tongue. In the second, they were presented with the task of listening to the recordings of seventeen mono-

\footnotetext{
${ }^{5}$ The Slovene General Matura in English has been aligned with the Common European Framework of Reference for Languages (CEFR; Council of Europe 2001) as a B2-level examination. The alignment project is presented and validated in Ilc \& Stopar (2015), as well as in Ilc et al. (2014).
} 


\section{Andrej Stopar: \\ Perception of General British monophthongs: The case of Slovene students of English as a foreign language}

syllabic (real and nonsense) words, and asked to identify the GB vowels embedded in these words.

The participants were told that some of the words were real words, while others were nonsense words, which were meant to eliminate any perceptual advantages provided by real words (cf. Pulvermüller 1999). In each of the three experimental stages, their choice of vowels was limited to four GB phonemes. The questionnaire clearly presented the targeted vowels by using their IPA symbols and providing a prototypical example for each of them. The examples were monosyllabic, highfrequency words that were spelled out and transcribed.

The stimuli used in the perception task were provided using IPA transcription, with a gap in the place of the targeted vowel: for example, "Word $1: / n \_t /$ ". For each of the four vowels, two real words and two nonsense words were listed in random order. Also, among the four words representing each vowel, two ended in a voiced and two in a voiceless consonant. To avoid any speculation on the potentially balanced distribution of the vowels in the task, an additional, seventeenth, word was recorded and added to the list.

The stimuli were played three times before the student responses were collected. The data were analysed using the statistical tools in Microsoft Excel and SPSS.

The following words were used in each of the three research stages:

- Stage 1 (2014-15): The stimuli in this stage included monosyllabic words with the lexical sets DRESS /e/, TRAP /æ/, STRUT / $/$, and NURSE $/ 3: / .{ }^{6}$ The DRESS-vowel /e/ words were /gret/, /med/, /streb/, and /tek/. The TRAP-vowel $/ æ /$ words were $/ \mathrm{bæd/,/dæp/,} \mathrm{/kæln/,} \mathrm{/læg/,} \mathrm{and} \mathrm{/mæp/.} \mathrm{The} \mathrm{STRUT} / \mathrm{\Lambda} /$ series included $/ \mathrm{f} \wedge \mathrm{y} /, / \mathrm{k} \Lambda \mathrm{t} /, / \mathrm{kr} \wedge \mathrm{p} /$, and $/ \mathrm{n} \wedge \mathrm{m} /$. And the stimuli with the NURSE /3:/ lexical set were /b3:d/, /ls:k/, /pls:p/, and /t3:g/.

- Stage 2 (2016-17): The stimuli included monosyllabic words with the STRUTvowel $/ \Lambda /{ }^{7}$ the PALM-vowel $/ \mathrm{a}: /$, the LOT-vowel $/ \mathrm{p} /$, and the THOUGHT-vowel $/ \mathrm{o} / /$. The words with the STRUT-vowel $/ \Lambda /$ were $/ \mathrm{f} \wedge \mathrm{y} /, / \mathrm{k} \Lambda \mathrm{t} /, / \mathrm{kr} \Lambda \mathrm{p} /$, and $/ \mathrm{n} \Lambda \mathrm{m} /$. The PALM-vowel /a:/ stimuli included /ka:t/,/na:m/, /fa:m/, and /kra:k/. The LOT-vowel $/ \mathrm{p} /$ words were $/ \mathrm{kpg} /, / \mathrm{npm} /, / \mathrm{fpt} /, / \mathrm{krpp} /$, and $/ \mathrm{bpt} /$. And the THOUGHT-vowel / $\mathrm{s} / /$ words were /ks:t/, /kro:p/, /no:g/, and /fo:m/.

\footnotetext{
${ }^{6}$ The GB schwa /a/ was not included in the experiment, as it does not appear in stressed syllables.

${ }^{7}$ The STRUT-vowel $/ \mathrm{N} / \mathrm{was}$ tested in the first and second stages of the experiment because of its hypothesised effect on the other phonemes examined.
} 
- Stage 3 (2017-18): The final set of stimuli included the FLEECE-vowel /i:/, the KIT-vowel /I/, the GOOSE-vowel /u:/, and the FOOT-vowel / $/$. The words representing the FLEECE-vowel /i:/ set were /fi:s/, /bi:g/, /fi:d/, and /li:s/.The KIT-vowel /I/ set included the stimuli /prt/, /nım/, /fit/, /krip/, and /brd/. The words with the GOOSE vowel were /hu:f/, /fu:m/, /mu:v/, and /kru:k/. And the FOOT-vowel / $/$ / words were /wod/, /bud/, /pvt/, and /krop/.

Based on the results of the initial (pre-training) experiments, it was decided that Stages 1 and 2 should be repeated at the end of the first semester, i.e. approximately four months after the initial testing, when the participants' formal instruction in phonetics and phonology was concluded. The aim was to acquire additional information on the participants' progress. Hence, they were asked to listen to the same sets of stimuli that were played in a changed order. The paired samples test and the Wilcoxon signed-rank test for related samples were used to check the significance of the differences between the pre-training and post-training data. The results presented herein include only the performance of those participants who sat for both (pre-training and the post-training) parts of the perception experiment.

The recordings of the stimuli were made by a native speaker of English with training in phonetics. The stimuli were processed in the software Praat (Boersma \& Weenink 2013) to check their F1 and F2 frequencies. The chart in Figure 2 illustrates the distribution of each stimulus in the vowel quadrilateral.

\subsection{Research questions}

The research questions addressed in the study are as follows.

Research Question 1: How do Slovene university students of EFL perform in their perception of the studied GB vowels?

Research Question 2: What are the most typical perception errors?

Research Question 3: Does explicit training in phonetics and phonology improve the perception of FL vowels? 


\section{Andrej Stopar: \\ Perception of General British monophthongs: The case of Slovene students of English as a foreign language}

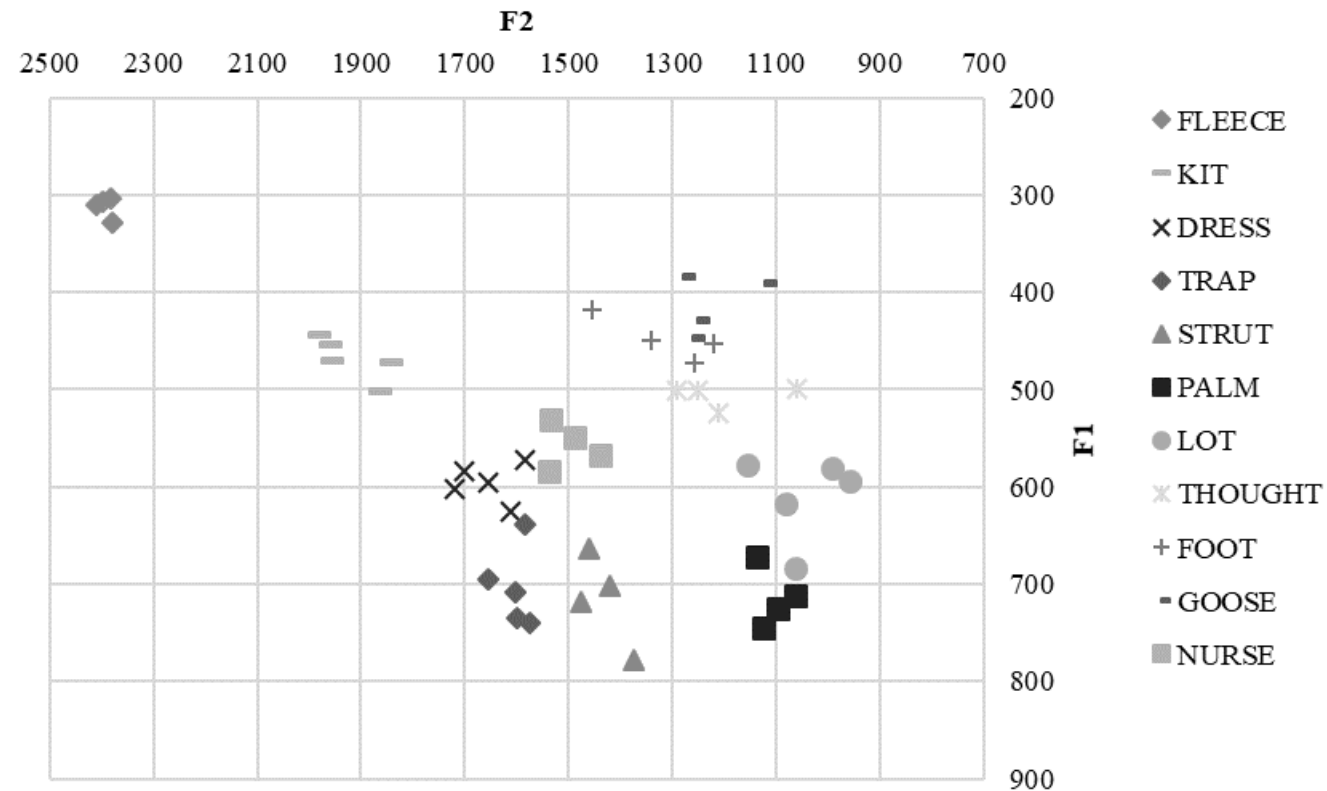

Figure 2. The F1 and F2 frequency measurements for the experimental stimuli ${ }^{8}$

\subsection{Results}

\subsubsection{Pre-training data}

The overall performance of the participants at the beginning of the first semester was $84 \%$ correct for all vowels tested (Stages 1, 2, and 3). Table 1 presents the results pertaining to the individual GB vowels in each of the three experimental stages (cf. Research Question 1).

The perception of Stage 1 GB lexical sets DRESS /e/, TRAP /æ/, STRUT / $\Lambda /$ and NURSE /3:/ shows that the TRAP-vowel /æ/ is the most challenging to perceive (57\% correct) and the NURSE vowel /3:/ the least challenging ( $89 \%$ correct). The overall result for the first four vowels tested was $70 \%$ correct.

The second set of vowels (Stage 2) was less demanding - among the GB vowels STRUT $/ \Lambda /$, PALM /a:/, LOT / $\mathrm{p} /$ and THOUGHT / $\mathrm{o}$ /, the LOT-vowel was the most problematic (79\% correct) and the THOUGHT-vowel / 0 :/ the least (91\% correct).

The final series of stimuli (Stage 3) was the least difficult to perceive for the participants: the average performance was very high, at $97 \%$ correct, with practi-

\footnotetext{
${ }^{8}$ Cf. Deterding (1997: 49-50), and Hawkins \& Midgley (2005: 186) for similar measurements of English speakers.
} 
cally no differences in the results for the GB vowels FLEECE /i:/, KIT /I/, GOOSE /u:/ and FOOT $/ \mho /$.

Table 1. Successful pre-training perception of GB vowels by Slovene EFL students

\begin{tabular}{|c|c|c|c|c|}
\hline \multicolumn{5}{|l|}{ Stage 1, Pre-training $(\mathrm{N}=54)$} \\
\hline Target Vowels & /e/ & $/ æ /$ & $/ \Lambda /$ & /3:/ \\
\hline Percentage Correct & 62 & 57 & 70 & 89 \\
\hline Average Performance (All Stimuli) & \multicolumn{4}{|l|}{70} \\
\hline \multicolumn{5}{|l|}{ Stage 2, Pre-training $(\mathrm{N}=82)$} \\
\hline Target Vowels & $/ \Lambda /$ & /a:/ & $/ \mathrm{p} /$ & /o:/ \\
\hline Percentage Correct & 81 & 84 & 79 & 91 \\
\hline Average Performance (All Stimuli) & \multicolumn{4}{|l|}{84} \\
\hline \multicolumn{5}{|l|}{ Stage 3, Pre-training $(\mathrm{N}=72)$} \\
\hline Target Vowels & /i:/ & $/ \mathrm{I} /$ & /u:/ & $/ \mho /$ \\
\hline Percentage Correct & 96 & 98 & 97 & 97 \\
\hline Average Performance (All Stimuli) & \multicolumn{4}{|l|}{97} \\
\hline Overall Performance (Stages 1, 2 and 3) & \multicolumn{4}{|l|}{84} \\
\hline
\end{tabular}

Table 2 presents the relationship between the successfully perceived stimuli and the most frequent erroneous answers (see Research Question 2).

Table 2. The main substitutes for the wrongly perceived vowels in the pre-training test (\% of instances)

\begin{tabular}{|c|c|c|c|c|}
\hline \multicolumn{5}{|l|}{ Stage 1} \\
\hline Target Vowel & $/ \mathrm{e} /(62 \%)$ & 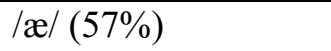 & $/ \Lambda /(70 \%)$ & /3:/ (89\%) \\
\hline Main Substitute & $/ æ /(29 \%)$ & $/ \mathrm{e} /(22 \%), / \Lambda /(19 \%)$ & $/ æ /(19 \%)$ & $/ \Lambda /(6 \%)$ \\
\hline \multicolumn{5}{|l|}{ Stage 2} \\
\hline Target Vowel & $/ \Lambda /(81 \%)$ & /a:/ (84\%) & $/ \mathrm{w} /(79 \%)$ & /o:/ (91\%) \\
\hline Main Substitute & /a:/ (4\%) & $/ \Lambda /(4 \%)$ & $/ 0: /(5 \%)$ & $/ \mathrm{p} /(3 \%)$ \\
\hline \multicolumn{5}{|l|}{ Stage 3} \\
\hline Target Vowel & /i:/ $(96 \%)$ & $/ \mathrm{I} /(98 \%)$ & /ひ/ (97\%) & $/ \mathrm{u}: /(97 \%)$ \\
\hline Main Substitute & $/ \mathrm{I} /(2 \%)$ & /i:/ (2\%) & $/ \mathrm{u}: /(3 \%)$ & $/ \mho /(3 \%)$ \\
\hline
\end{tabular}

Stage 1 of the experiment shows that the least successfully perceived GB vowels the DRESS- /e/ and the TRAP-vowel /æ/ - were interchangeable for a high number of listeners. A noticeably high percentage of participants also chose the STRUT-vowel $/ \Lambda /$ as a replacement for the TRAP-vowel $/ æ /$. The STRUT-vowel $/ \Lambda /$ was also most commonly mistaken for the TRAP-vowel /æ/, while the NURSE-vowel/3:/ was often 


\section{Andrej Stopar: \\ Perception of General British monophthongs: The case of Slovene students of English as a foreign language}

confused with the STRUT-vowel $/ \mathrm{N} /$. The perception of vowels in nonsense words was routinely more demanding for the participants: the average success rates were $67 \%$ for nonsense words, and $71 \%$ for real words. For example, the nonsense words /streb/ and /t $3: \mathrm{g} /$ were very frequently heard as /stræb/ and $/ \mathrm{t} \Lambda \mathrm{g} /$. The data show that in all but one case, the most poorly discriminated stimuli were nonsense words, with the exception of the real word $<$ cut $>/ \mathrm{k} \Lambda \mathrm{t} /$, which had the lowest result among the four STRUT-words $/ \mathrm{h} /$, since it was often heard as $<$ cat $>/ \mathrm{krt} /$. The voicing of the consonant following the observed vowel had no observable effect on the results.

The most challenging Stage 2 phoneme was the LOT-vowel /p/, which was frequently confused with the THOUGHT-vowel / $\mathrm{s} / /$ (and vice versa). Similarly, the PALM-vowel /a:/ was typically heard as the STRUT-vowel $/ \mathrm{N} /$ (and vice versa). A further examination of the results shows that the substitution of the long PALM /a:/ with the short STRUT $/ \Lambda /$ occurred most often in instances where the word ended in a voiceless consonant, namely, in the stimuli $/ \mathrm{kra}: \mathrm{k} /$ and $/ \mathrm{ka}: \mathrm{t} /$. The effect of prefortis clipping can also be observed in the THOUGHT-vowel /o:/, where the stimuli $/ \mathrm{kro}: \mathrm{p} /$ and $/ \mathrm{ks}: \mathrm{t} /$ were the most difficult for the participants. The most poorly perceived stimulus in the STRUT-vowel $/ \Lambda /$ series was $/ \mathrm{n} \Lambda \mathrm{m} /$, while among the LOTvowel $/ \mathrm{p} /$ words the most challenging one was $/ \mathrm{fpt} /$. The effect of nonsense words can be observed in this stage of the experiment as well: the participants successfully identified the phonemes in $82 \%$ of nonsense words, and $85 \%$ of real words. With regard to the possible interaction between the GB, GA and StS vowel systems, it should be noted that the GB LOT /p/ was very rarely perceived as PALM /a:/. Furthermore, the THOUGHT-vowel / $/$ :/ was often confused with LOT $/ \mathrm{p} /$, and rarely with $\operatorname{PALM} / \mathrm{a} /$.

Stage 3 showed that the perception of GB close to close-mid vowels (FLEECE /i:/, KIT/I/, FOOT / $/$ /, and GOOSE /u:/) by Slovene EFL learners is outstanding, with the average result for the four phonemes in the pre-training experiment being $97 \%$. The misperceptions that occur typically include the switch between the FLEECE- /i:/ and the KIT-vowels /I/, or the one between the GOOSE- $/ \mathrm{u}$ :/ and the FOOT-vowels $/ \mho /$. The only other misperception was the vowel KIT /I/, which was misheard (twice) as FOOT $/ \mho /$ in the stimulus $/ \mathrm{nIm} /$. The lowest perception success rates that were observed were related to nonsense words, for example, $90 \%$ for $/ \mathrm{bi}: \mathrm{g} /$ and $94 \%$ for /nIm/. 


\subsubsection{Post-training data}

Table 3 presents the results of the post-training perception test for Stages 1 and 2 of the experiment (cf. Research Question 3 above). The post-training part for Stage 3 was not conducted owing to the high results in the pre-training experiment.

The perception of Stage 1 vowels was significantly improved by the end of the semester: the average score for the four vowels had risen from $70 \%$ to $83 \%$ with all but one student improving their result. The null hypothesis that there is no difference between the two sets of data was rejected $(p<0.005)$. Despite the noticeable improvement in the recognition of the stimuli - especially in the cases of the TRAP$/ \mathfrak{x} /$ and STRUT-vowels $/ \mathrm{\Lambda} /(18 \%$ points $)$ - it can be observed that both the DRESS- /e/ and the TRAP-vowels /æ/ remained challenging for the participants even after the training they received in the first semester: the post-training averages amounted to $70 \%$ and $75 \%$, respectively. The NURSE-vowel /3:/ was the least problematic of the four, with the final successful perception result of $97 \%$ correct.

Table 3. Successful post-training perception of GB vowels by Slovene EFL students

\begin{tabular}{|c|c|c|c|c|}
\hline \multicolumn{5}{|l|}{ Stage 1, Post-training $(\mathrm{N}=54)$} \\
\hline Target Vowels & $/ \mathrm{e} /$ & $/ \mathfrak{|} /$ & $/ \mathrm{h} /$ & /3:/ \\
\hline Percentage Correct & 70 & 75 & 88 & 97 \\
\hline Change (in \% points) & +8 & +18 & +18 & +8 \\
\hline Average Performance (All Stimuli) & \multicolumn{4}{|l|}{83} \\
\hline \multicolumn{5}{|l|}{ Stage 2, Post-training $(\mathrm{N}=72)$} \\
\hline Target Vowels & $/ \mathrm{A} /$ & $/ \mathrm{a}: /$ & $/ \mathrm{p} /$ & /o:/ \\
\hline Percentage Correct & 94 & 95 & 94 & 97 \\
\hline Change (in \% points) & +13 & +11 & +15 & +6 \\
\hline Average Performance (All Stimuli) & \multicolumn{4}{|l|}{95} \\
\hline \multicolumn{5}{|l|}{ Stage 3, Post-training $(\mathrm{N}=82)$} \\
\hline $\mathrm{n} / \mathrm{a}$ & & & & \\
\hline
\end{tabular}

For the Stage 2 vowels it can be observed that the post-training result was also significantly improved. The null hypothesis that there is no difference between the two sets of data was rejected $(\mathrm{p}<0.05)$. At the end of the semester, $54 \%$ of the participants correctly identified all the vowels tested by the stimuli, while the rest of the respondents achieved a result between $65 \%$ and $94 \%$. Furthermore, $93 \%$ of the participants showed progress in the perception performance, while only $7 \%$ performed slightly worse at the end of the semester, scoring one misperceived word more than on the pre-training test. Considering the vowels individually, it should 


\section{Andrej Stopar: \\ Perception of General British monophthongs: The case of Slovene students of English as a foreign language}

be noted that the all final discrimination results are well above $90 \%$. The improvement is most evident in the case of the LOT-vowel / $\mathrm{p} /$ (from $79 \%$ to $94 \%$ correct); however, a similar improvement was detected for the STRUT $/ \mathrm{N} /$ and PALM /a:/ lexical sets (from $81 \%$ to $94 \%$ and from $84 \%$ to $95 \%$, respectively), whereas the THOUGHT words $/ 0$ :/ were perceived correctly $97 \%$ of the time $(91 \%$ in the pretraining part).

\section{Discussion}

\subsection{Stage 1 vowels}

Concerning the series DRESS /e/, TRAP /æ/, STRUT / $\Lambda$, and NURSE / $3: /$, it can be concluded that the previously observed production failures with the vowels /e/ and /æ/ (cf. Šuštaršič 2005; Komar 2017; Čubrović 2017) are also mirrored in the perception of these phonemes. The results for this vowel pair match the findings by Marković (2009) for Serbian, which she attributed to the transfer of L1 phonological categories. We also assume that the poor performance in this case can be predicted from the differences between the Slovene and GB vowel spaces. This contrast is also quantified by the inclusion of $/ N /$ and $/ 3: /$ in Stage 1 of the experiment. The vowels STRUT / $\mathrm{N} /$ and NURSE /3:/ are more easily assimilated into the Slovene vowel categories, which is confirmed by the more successful perception of the participants.

A closer scrutiny of the wrongly perceived stimuli provides additional backing to the claims by Šuštaršič (2005) and Komar (2017) that the DRESS /e/ and the TRAP $/ \mathfrak{~} /$ are sometimes produced as interchangeable by Slovene EFL speakers. In the case of perception, the different positions of speech organs in English and Slovene result in a "perceptual confusion" (Tatham \& Morton 2011: 160). An examination of the relevant sections of the vowel systems also explains the perceptual confusion related to the substitution of the central NURSE-vowel /3:/ with the (centralised) STRUT $/ \Lambda /$, as the two vowels are close to each other. The frequent replacement of the STRUT-vowel $/ \Lambda /$ with the TRAP $/ \mathfrak{a} /$, on the other hand, can be explained by relying on Cruttenden (2014: 120) and his explanation that the tendency of $/ æ /$ and $/ \mathrm{N} /$ to become "more open" may lead to the occasional "neutralisation" of the two phonemes.

With regard to pedagogical implications, it should be pointed out that confusing the STRUT-vowel $/ \Lambda /$ with the TRAP-vowel $/ \mathfrak{a} /$ is undesirable. This substitution combined with the new notation introduced in Gimson's Pronunciation of English (Cruttenden 2014: 119-121) - /a/ instead of /æ/ for the TRAP-vowel /æ/ - may pre- 


\section{EZIKOSLOVLJE \\ 20.3 (2019): 475-496}

sent a new obstacle for learners/teachers of GB phonetics and phonology. Namely, if the students interpret the new notation as one requiring a more open variant of the TRAP-vowel /æ/, this may cause additional difficulties in their perception of the open-mid to open variant of the vowel. To provide an example: the oft-discussed Slovene production/perception issue with the pair $<$ met $>$ met/ and $<$ mat $>$ /mæt/ could grow into an even larger problem with the merging of the otherwise distinct vowels in $<$ met $>/$ met $/,<$ mat $>/$ mæt $/$, and $<$ mutt $>/$ mst $/$.

\subsection{Stage 2 vowels}

Considering the Stage 2 vowel set of the STRUT-vowel $/ \mathrm{N} /$, the PALM-vowel /a:/, the LOT-vowel $/ \mathfrak{p} /$, and the THOUGHT-vowel $/ \mathrm{s}: /$, it can be concluded that the observed phonemes were successfully perceived. In the pre-training stage the participants correctly identified $84 \%$ of the stimuli, which suggests that this section of the GB vowel space is less challenging for Slovene listeners than the one considered in the first stage of the experiment.

The study of Stage 2 vowels has also identified some factors that influence the perception of these and may have teaching implications. For example, at first glance, the substitution of long vowels with short ones (and vice versa) may lead us to believe that vowel length is not a relevant factor in vowel perception. However, a more thorough inspection of the data reveals that a long vowel is much more readily misperceived as a short one in cases when the stimulus ends in a voiceless consonant. To give an example: the target vowel PALM /a:/ in the stimuli /na:m/ and $/ \mathrm{ka}: \mathrm{t} /$ was correctly identified in $94 \%$ and $63 \%$ of the responses, respectively. The allophonic phenomenon of pre-fortis clipping (Wells 2008: 155) should thus be considered a contributing element in the successful perception of these vowels. As previously attested in the literature (Walsh \& Parker 1981), the length of the vowel also indicates the voicing of the postvocalic consonant. Thus, vowel length can be seen as an important acoustic parameter (Tatham \& Morton 2011) that importantly defines the segments targeted by the experiment.

Another aspect that is noteworthy pertains to analysis of the nonsense word $/ \mathrm{fpt} /$. In the case of this stimulus, the aim of the participants seemed to have been to classify the word as a real one. Hence they interpreted it as the pronunciation of the word $<$ fought $>/$ fo:t/. This, incidentally, also points out to the usefulness of nonsense words in perception training. The experiment thus also confirms the processing differences between real words and nonsense words that have been previously identified in the literature (see, for example, Pulvermüller 1999). 


\section{Andrej Stopar: \\ Perception of General British monophthongs: The case of Slovene students of English as a foreign language}

In Section 1.2 it was predicted that the American pronunciation could influence the perception of GB vowels, especially the ones in the THOUGHT / $/$ :/ lexical set (Cruttenden 2014: 129; see also Ladefoged 1999). Interestingly, the prediction has not been confirmed because the vowel was very successfully discriminated by the participants. Regardless, the data shows that the relationship between the GB THOUGHT-vowel / $/$ :/ and the GA vowels $/ \mathrm{a} /$ or $/ \mathrm{s} /$ can be confusing for the learners. We believe that the GB stimulus /fpt/ was in fact heard as GA /fpt/ ('fought') and in turn erroneously matched with the GB THOUGHT / $\mathrm{s}$ // lexical set. Such an interpretation of the data would explain why the nonsense word /fpt/ was the most challenging LOT-word in the experiment, and why it was classified as a THOUGHTvowel / $/$ :/ word in more than $31 \%$ of the responses. The finding demonstrates that the interpretation of the FL vowel space can be simultaneously affected by more than one variety of the target language.

\subsection{Stage 3 vowels}

The vowels included in the third stage of the experiment were from the FLEECE /i:/, $\mathrm{KIT} / \mathrm{I} /$, GOOSE /u:/, and FOOT / $\mathrm{\mho} /$ lexical sets. A general observation is that all the observed vowels in this series were perceived exceptionally well (the overall average was 97\%). The rare misperceptions included the substitution of long vowels with short ones (and vice versa); however, owing to the extremely high vowel recognition level, it is impossible to claim that vowel length or pre-fortis clipping are the relevant factors influencing the wrongly perceived stimuli, as was the case with the vowels in the second experimental stage.

Šuštaršič's (2005: 12) claims pertaining to the GB vowels FLEECE /i:/ and KIT /I/ are only partially confirmed: the Slovene EFL listeners do seem to neutralise the difference between them, yet this occurs very rarely in perception. The two phonemes are so far apart in the vowel space that their discrimination is obviously not an issue. In line with Flege (1995), it can be claimed that the distance between the two sounds enabled the participants to form a new vowel category. Moreover, the cases when the KIT-vowel/I/ was wrongly heard as the FOOT-vowel / $/ /$ can be attributed to the relative closeness of the two vowels to the central part of the quadrilateral.

Regarding the opposition of the GB GOOSE /u:/ and FOOT / $/$ / lexical sets, we conclude that the similarity of StS /u/ to the GB GOOSE-vowel (Šuštaršič 2005) likely aided the participants with their identification of the targeted sounds. The position of $\mathrm{StS} / \mathrm{u} /$ in-between the two potential GB vowel matches that was identified by Šuštaršič does not act as a distractor in perception. 
Finally, Stage 3 of the experiment also confirms that the likelihood of perception errors increases when nonsense words are used.

\subsection{Post-training results}

Since the perception performance in the first two stages of the experiment proved to be problematic for many students at the beginning of their studies at the English Department, the same participants were asked to re-take the test at the end of the semester. The results of the post-training tests are encouraging. The findings show that the participants' perception performance had significantly $(p<0.005$ and $\mathrm{p}<0.05$ for Stages 1 and 2 of the experiment, respectively) and substantially improved in the course of approximately four months. This shows that vowel perception in upper-intermediate to advanced adult learners can be improved when supported by continuous theoretical and practical instruction. The finding confirms Saito's observations (2012) about the benefits of explicit instruction of pronunciation.

While the pre-training stage showed that the participants' recognition of the stimuli varied greatly - in Stage 1 the lowest overall score received by an individual participant was $24 \%$ correct, while in Stage 2 the lowest result was $42 \%$ - this variation was much less apparent in the post-training part, with the lowest results there being $53 \%$ and $65 \%$ correct. It should be noted that the strongest performers were able to maintain their results, while the weaker students made progress.

An examination of the individual vowels indicates improvement across the board as well. The pre-training percentages were between $62 \%$ and $89 \%$, whereas the post-training ones were significantly higher, between $70 \%$ and $97 \%$. The findings suggest that the most challenging section of the GB quadrilateral is the one with the vowels DRESS /e/, TRAP /æ/ and STRUT $/ \Lambda /$. Also problematic for the participants were the vowels of the LOT and THOUGHT / $\mathrm{s}$ // lexical set. Contrary to some predictions, almost no issues were identified with regard to the vowel pairs KIT /I/FLEECE /i:/ and FOOT/ / / GOOSE / $\mathrm{u}: /$, which shows that the mispronunciations in the production of these vowels (identified by Šuštaršič 2005: 12) are not always mirrored in their perception.

\section{Conclusion}

The experimental study presents how Slovene students of EFL perceive GB monophthongs embedded in monosyllabic stimuli. The findings confirm the crucial 


\section{Andrej Stopar: \\ Perception of General British monophthongs: The case of Slovene students of English as a foreign language}

function that that the L1 vowel system fulfils in the acquisition of FL vowel phonemes: the acquired L1 vowel categories can both aid as well as distract from proficient FL perception.

The study shows that not all of the observed GB vowels are overly difficult to recognise. Some of the GB vowels were easily assimilated to the existing native categories (for example, the NURSE-vowel /3:/), while for others new categories were created (for example, for the KIT-vowel). The more problematic parts of the vowel space, however, are represented by the vowels that were most likely assimilated to the same native category, especially the GB vowels DRESS /e/ and TRAP/æ/ (with some intrusion by the STRUT-vowel $/ \Lambda /$ as well).

These findings also indicate that a contrastive approach to the vowel systems does not always yield the desired results, as some of the initial predictions about the possible perception difficulties were not borne out (see the pairs FOOT $/ \mathrm{v} /$ GOOSE /u:/ and KIT/I/-FLEECE/i:/). Moreover, such an approach fails to consider the different varieties of the target language that can influence the parameters of the FL vowel space. The participants in this experiment, for example, are regularly exposed to both American and British English.

Finally, the comparison of the results of the pre-training and post-training stages confirms that explicit theoretical and practical instruction in English phonetics and phonology contributes to the successful perception of vowel contrasts in EFL. Moreover, the findings can be utilised in the FL instruction context, since they clearly point to the GB vowels deserving additional attention in the learning process.

\section{References}

Baker, Wendy \& Trofimovich Pavel. 2006. Perceptual paths to accurate production of L2 vowels: The role of individual differences. International Review of Applied Linguistics in Language Teaching 44(3). 231-250. https://doi.org/10.1515/IRAL.2006.010

Best, Catherine T. 1995. A direct realist view of cross-language speech perception. In Strange, Winifred (ed.), Speech perception and linguistic experience: theoretical and methodological issues, 171-203. Baltimore: York Press.

Boersma, Paul \& Weenink, David. 2013. Praat: doing phonetics by computer. Version 5.3.51. http://www.praat.org/

Bion, Ricardo A. H. \& Escudero, Paola \& Rauber, Andréia S. \& Baptista, Barbara O. 2006. Category formation and the role of spectral quality in the perception and production of English front vowels. In International conference on spoken language pro- 


\section{EZIKOSLOVLJE \\ 20.3 (2019): 475-496}

cessing, Proceedings of INTERSPEECH 2006 - ICSLP, 1363-1366. Bonn: International Speech Communication Association.

Collins, Beverley \& den Hollander, S. P. \& Mees, Inger M. \& Rodd, Jill. 2006. Sounding better: a practical guide to English pronunciation for speakers of Dutch. Holten: Walvaboek.

Collins, Beverley \& Šuštaršič, Rastislav \& Komar, Smiljana. 2014. Present-day English pronunciation, a guide for Slovene students, revised and enlarged 2 nd edition. Ljubljana: Znanstvena založba Filozofske fakultete.

Council of Europe. 2001. Common European framework of reference for languages: learning, teaching, assessment. Cambridge: Cambridge University Press.

Cruttenden, Alan. 2014. Gimson's pronunciation of English. $8^{\text {th }}$ edn. London: Routledge.

Čubrović, Biljana. 2017. The acoustic characteristics of non-native American English vowels. Linguistica 57(1). 59-72. https://doi.org/10.4312/linguistica.57.1.59-72.

Čubrović, Biljana. 2019. Duration as a phonetic cue in native and non-native American English. English Language Overseas Perspectives and Enquiries 16(1). 15-28. https://doi.org/10.4312/elope.16.1.15-28

Deterding, David. 1997. The formants of monophthong vowels in Standard Southern British English pronunciation. Journal of the International Phonetic Association 27(1-2). 47-55. https://doi.org/10.1017/S0025100300005417

Escudero, Paola. 2000. The perception of English vowel contrasts: acoustic cue reliance in the development of new contrasts. In James, Allan \& Leather, Jonathan (eds.), New Sounds 2000: Proceedings of the Fourth International Symposium on the Acquisition of Second Language Speech, 122-131. Klagenfurt: University of Klagenfurt.

Flege, Jim E. 1995. Second language speech learning: theory, findings and problems. In Strange, Winifred (ed.), Speech perception and linguistic experience: theoretical and methodological Issues, 233-272. Baltimore: York Press.

Hawkins, Sarah \& Midgley, Jonathan. 2005. Formant frequencies of RP monophthongs in four age groups of speakers. Journal of the International Phonetic Association 35(2). 183-199. https://doi.org/10.1017/S0025100305002124

Hirci, Nataša. 2017. Investigating trainee translators' views on the pronunciation of English: a Slovene perspective. Linguistica 57(1). 93-106. https://doi.org/10.4312/linguistica.57.1.93-106

Ilc, Gašper \& Rot Gabrovec, Veronika \& Stopar, Andrej. 2014. Relating the Slovenian secondary school English language national examinations to the CEFR: findings and implications. Linguistica 54(1). 293-308. https://doi.org/10.4312/linguistica.54.1.293308

Ilc, Gašper \& Stopar, Andrej. 2015. Validating the Slovenian national alignment to CEFR: the case of the B2 reading comprehension examination in English. Language Testing 32(4). 443-462. https://doi.org/10.1177/0265532214562098 


\section{Andrej Stopar: \\ Perception of General British monophthongs: The case of Slovene students of English as a foreign language}

International Phonetic Association. 1999. Handbook of the International Phonetic Association, A guide to the use of the International Phonetic Alphabet. Cambridge: Cambridge University Press.

Jurančič Petek, Klementina. 2014. The "magnet effect" - a powerful source of L1 dialect interference in the pronunciation of English as a foreign language. ELOPE, English Language Overseas Perspectives and Enquiries 11(1). 45-64. https://doi.org/10.4312/elope.11.1.45-64

Komar, Smiljana. 2017. The relationship between the perception and production of four General British vowels by Slovene university students of English. Linguistica 57(1). 161-170. https://doi.org/10.4312/linguistica.57.1.161-170

Ladefoged, Peter. 1999. American English. In International Phonetic Association, Handbook of the International Phonetic Association, A guide to the use of the International Phonetic Alphabet, 41-44. Cambridge: Cambridge University Press.

Liberman, Alvin M. \& Cooper, F. S. \& Shankweiler, Donald P. \& Studdert-Kennedy, Michael. 1967. Perception of the speech code. Psychological Review 74(6). 431-461.

Marković, Maja. 2009. The perception and production of the English vowels /e/ and /æ/ by native speakers of Serbian. In Tsangalidis, Anastasios (ed.), Selected Papers from the 18th International Symposium on Theoretical and Applied Linguistics, Thessaloniki, 46 May 2007, 253-262. Thessaloniki: Department of Theoretical and Applied Linguistics, School of English, Aristotle University of Thessaloniki. http://ejournals.lib.auth.gr/thal/article/view/5444

Petek, Bojan \& Šuštaršič, Rastislav \& Komar, Smiljana. 1996. An acoustic analysis of contemporary vowels of the Standard Slovenian language. In Bunnell, H Timothy \& Idsardi, William (eds.), Proceedings ICSLP 96 / Fourth International Conference on Spoken Language Processing, October 3-6, 1996, Philadelphia, PA, USA, 133-136. Wilmington, DE: University of Delaware, Applied Science and Engineering Laboratories, Alfred I. du Point Institute. https://doi.org/10.1109/ICSLP.1996.607055

Pulvermüller, Friedemann. 1999. Words in the brain's language. Behavioral and brain sciences 22(2). 253-279. https://doi.org/10.1017/S0140525X9900182X

Saito, Kazuya. 2012. Effects of Instruction on L2 Pronunciation Development: A Synthesis of 15 Quasi-Experimental Intervention Studies. TESOL Quarterly 46. 842-854. https://doi.org/10.1002/tesq.67

Srebot-Rejec, Tatjana. 1988a. Kakovost slovenskih in angleških samoglasnikov (kontrastivna analiza obeh sestavov po njihovi kakovost $\mathrm{s}$ stališča akustične, artikulacijske in avditivne fonetike). Jezik in slovstvo 34(3). 57-64.

Srebot-Rejec, Tatjana. 1988b. Word accent and vowel duration in Standard Slovene. An acoustic and linguistic investigation. Munich: Verlag Otto Sagner.

Stopar, Andrej. 2015. Perception of four General British vowels by Slovenian university students of English as a foreign language. In Przedlacka, Joanna \& Maidment, John \& Ashby, Michael, PTLC2015: proceedings of the Phonetics Teaching and Learning 
Conference, London, 5-7 August 2015, 87-90. London: Phonetics Teaching and Learning Conference.

Stopar, Andrej. 2017. Perception of the GB vowels / / , /a:/, /p/, AND / / :/ by Slovenian speakers of English. In Phonetics Teaching and Learning Conference, PTLC2017: proceedings of the Phonetics Teaching and Learning Conference UCL, London, 9-1 August 2017, 104-109. London: Phonetics Teaching and Learning Conference. https://www.ucl.ac.uk/drupal/site_pals/sites/pals/files/migrated-files/PTLCProceedings-2017.pdf

Strange, Winifred (ed.). 1995. Speech perception and linguistic experience: theoretical and methodological issues. Baltimore: York Press.

Šuštaršič, Rastislav. 2004. A contrastive analysis of the vowel qualities of English and Slovene. In González-Álvarez, Elsa \& Rollings, Andrew (eds.), Studies in Contrastive Linguistics, 601-608. Santiago de Compostela: Universidade de Santiago de Compostela.

Šuštaršič, Rastislav. 2005. English-Slovene contrastive phonetic and phonemic analysis and its application in teaching English phonetics and phonology. Ljubljana: Znanstveni inštitut Filozofske Fakultete.

Šuštaršič, Rastislav \& Komar, Smiljana. 1999. Slovene. In International Phonetic Association, Handbook of the International Phonetic Association, A guide to the use of the International Phonetic Alphabet, 135-139. Cambridge: Cambridge University Press.

Šuštaršič, Rastislav \& Komar, Smiljana \& Petek, Bojan. 1995. Illustration of the IPA: Slovene. Journal of the International Phonetic Association 25(2). 86-90. Dublin: IPA.

Tatham, Mark \& Morton, Katherine. 2011. A guide to speech production and perception. Edinburgh: Edinburgh University Press.

Walsh, Thomas \& Parker, Frank. 1981. Vowel length and 'voicing' in a following consonant. Journal of Phonetics 9. 305-308.

Wells, J. C. 1982. Accents of English. Cambridge: Cambridge University Press.

Wells, J. C. 2008. Longman pronunciation dictionary. 3rd edn. Harlow: Pearson Education Limited.

\section{Author's address:}

University of Ljubljana

Faculty of Arts, Department of English

Aškerčeva cesta 2

1000 Ljubljana

E-mail: Andrej.Stopar@ff.uni-lj.si 


\section{Andrej Stopar: \\ Perception of General British monophthongs: The case of Slovene students of English as a foreign language}

\section{PERCEPCIJA JEDNOGLASNIKA STANDARDNOGA ENGLESKOG JEZIKA U SLOVEN- SKIH STUDENATA KOJIMA JE ENGLESKI STRANI JEZIK}

Rad predstavlja eksperimentalno istraživanje o percepciji jednoglasnika standardnoga engleskog jezika, koje je provedeno u trima etapama, u razdoblju od 2014. do 2018. godine. Promatrani vokali istraženi su (i) usporedbom engleskoga i slovenskoga vokalskog sustava te (ii) provođenjem eksperimenta u njihovoj percepciji. Raščlambom se u središte pozornosti stavlja ukupna izvedba sudionika, najučestalije neusklađenosti u poimanju te njihovo napredovanje tijekom nastave unutar jednoga semestra. Rezultati ukazuju na činjenicu: da se promatrana izvedba iz prethodnih istraživanja odražava i u poteškoćama u percepciji jednoglasnika, da usporedbom vokalskih sustava nije u potpunosti moguće predvidjeti diskriminacijske pogreške kod vokala stranoga jezika, da se opreke kod novih vokala usvajaju / izjednačavaju na različite načine te da se percepcija fonema stranoga jezika prema jasno izloženim uputama može poboljšati.

Ključne riječi: percepcija vokala; vokali standardnoga engleskog jezika; slovenski vokali; fonetika stranoga jezika; slovenski studenti engleskoga kao stranoga jezika. 